\title{
Land and Property Taxation on Land and Infrastructural Development in Lagos and Rivers States, Nigeria
}

\author{
Chukwu Johnkennedy Obinna* \\ Department of Linguistic and Communication Studies, Nigeria
}

*Corresponding author: Chukwu Johnkennedy Obinna, Department of Linguistic and Communication Studies, Faculty of Humanities, University of Port Harcourt, Choba, Nigeria.

Received Date: January 08, 2019

Published Date: February 05, 2019

\begin{abstract}
Increasing demand for urban and rural infrastructures and dwindling revenue allocations in Nigeria have informed the Lagos State Government to promulgate Land Use Charge Law (2001) as a way of increasing internally-generated revenues through property tax. The Law stipulates a formula for assessing the Charge payable on properties in Lagos State, amongst other provisions. These cannot be said of Rivers State hence the recommendation that the State should harness the Property taxation laws in the State with a bid to generate revenue as is done in Lagos State. The aim of this paper is to determine the role of Land and Property taxation on land and infrastructural development in Lagos and Rivers States.
\end{abstract}

Keywords: Land, Property taxation on land, Infrastructural development

\section{Introduction}

Human society the world over is heavily dependent on land and its resources. It is not an overstatement to say that without land there would be no human existence. This is because it is from land that man gets items very essential for his survival such as food, fuel, clothing, shelter, medication and others [1]. Omotola succinctly puts it thus:

Every person requires land for his support, preservation and self-actualization within the general ideals of the society. Land is the foundation of shelter, food and employment. Man lives on land during his life and upon his demise, his remains are kept in it permanently. Even where the remains are cremated, the ashes eventually settle on land. It is therefore crucial to the existence of the individual and the society. It is inseparable from the concept of the society. Man has been aptly described as a land animal [2].

It is, also from land that government, through property taxation, generates some of its revenue from which its survival depends, both in providing infrastructure and development of the society. From the foregoing, it is obvious that the life of man and that of the society revolve around land and its resources. Thus, it is apposite that man's fulfillment of his potentials in life, including that of government, depends, largely, on their relationship with land. Global recognition of the relevance of land to the society can be gleaned from the proceedings at the United Nations Conference on Human Settlement (Habitat II) 1996 where many countries committed themselves to:

promoting optimal use of productive land in urban and rural areas and protecting fragile ecosystems and environmentally vulnerable areas from the negative impacts of human settlements, inter alia, through developing and supporting the implementation of improved land management practices that deal comprehensively with potentially competing land requirements for agriculture, industry, transport, urban development, green space, protected areas and other vital needs [3].

It is this importance of land to man and the society that influenced the State (including Lagos and Rivers states) intrusion into Property tax legislation in order to generate revenue for infrastructural development, and by extension, ensure adequate and efficient land management technique for the benefits of the 
greatest number of the members of the society. This point is further underscored in the words of a learned author [4] to wit:

It has long been recognized by Economists and other behavioral scientist that land is an important factor of production that has an almost inelastic supply curve. Virtually every form of investment or development by government and private entities is dependent upon land in one way or another. It is now generally accepted that poor land administration can impede economic development and social welfare. Therefore, instructively, this paper shall focus on the role of land and property taxation on land and infrastructural development in Lagos and Rivers states. Efforts will be made to espouse the impact of land and property taxation in the two jurisdictions, the legal regimes, the challenge, Land and infrastructural development, infrastructural development in Rivers and Lagos states, and others, also to rummage into the labyrinth of related postulations.

The impact of land and property taxation on Land and infrastructural development in Lagos and Rivers states. The responsibility of Governments at all levels in providing infrastructural development is enormous. Such infrastructure may be in the rural and urban centers, they include roads, sewers, or utility lines, hospitals, schools, emergency services like fire fighters and police, sidewalks, or ponds to hold storm-water [5]. These basic facilities make a town or city to function effectively, and, are also, required for national development as observed by Collins [6] and Tesfay [7]. Funding of infrastructure, especially in urban areas in time of dwindling revenue allocations from the Federal Government, has posed great challenge to State and Local Council Governments. This has led the Lagos State Government and other states to source for a new means of generating additional revenue internally through property tax. The Land Use Charge Law 2001 was therefore a creation of the Lagos State Government to give legal backing to revenue generation through property taxation in order to provide sustainable housing and other infrastructural development. This, in Lagos, has helped the state to increase its internally generated revenue, which, before the advent of this law, was in abysmal state. And the proceed therefrom has, also, been ploughed back into the infrastructural development of the state as may be seen in the gigantic projects embarked upon by the state Government - the Eko Atlantic city, roads, etc. and as noted by Osibanjo [8] that "it is clear that the Land Use Charge is not an extraordinary invention, but a viable tool used worldwide for social development". It should also be noted that Lagos state stand outstanding in this and in the area of collection of property tax much more than Rivers state, whose activities in this regard, is still in doldrums. However, Rivers state has made tremendous efforts in the collection of other property taxes, like Stamp Duty, certificate of occupancy fee, etc. And it is uncertain whether this has reflected in the infrastructural development of the state.

\section{The Challenge: Lagos State Example}

The rate of urbanization in Nigeria has tremendously increased in the last two decades. Census in the early fifties showed that about $10.6 \%$ of the total population lived in the cities. This rose dramatically to $19.1 \%$ in 1963 , and $24.5 \%$ in 1985 . Today, the national population is estimated to be 150 million with the urban population constituting of about 30\%. The Lagos metropolis has grown in terms of population. According to the 1991 national census, Lagos State had a population of 5, 725116 out of a national total of 88992220 . Although the 2006 National Census credited the metropolitan area with a population figure of 7, 937 932, the more reliable population figure given by the Lagos State Government is 17,553924 based on enumeration that was conducted for social planning. This population figure is projected to reach 24.5 million by the year 2015, thereby making it to be among the ten most populous cities in the world [9] and the only state in Nigeria that is highly urbanized. Which, without other sources of revenue may not be able to cater for its' increasing population in this era of dwindling oil revenue and decline in the flow of income from the Federation account. Herein lays the need for the diversification of the revenue base of the State and the inevitable importance of Land and property taxation comes handy - as the only panacea to the untoward situation.

\section{Land and Infrastructural Development}

Land is an invaluable resource, therefore, the need to, at all times, preserve it is important due to the fact that government at all levels require land to carry-out its infrastructural development and to generate revenue through property taxation. Food and Agricultural Organization of United Nations (FAO) had alluded to the above when it said that "Land tenure is an important part of social, political and economic structures" [10]. Similarly, Olusegun [11] opined that "in one way or another, land provides the shelter, privacy, infrastructure and services that are essential in sustaining modern life". This makes land the bulwark for infrastructural development and one of the most significant platform from which government generate revenue - property tax. From the foregoing, it evidently clear that without land no meaningful development can take place in the society, including Lagos and Rivers state. It therefore, suffice that there is a nexus between Land, Property tax and infrastructural development, and the role of the two (Land and Property tax) on infrastructural development cannot be over emphasized. As also, observed by Tsoodle and Turner [12] when they said that Property taxes are a fundamental source of wealth for Local Governments in the United States, and they make up to $73 \%$ of Local Government tax revenue. Similarly, almost all local governments worldwide rely to some extent on property taxes to pay for local services [13]. And a substantial portion of it (property taxes) in the United States were levied on residential property owners, and these property owners in turn benefited from the municipal services that those property taxes helped to finance [14].

\section{Property Tax, Residential Building and Infrastructural Development}

In developed nations of the world, Property taxes are used to finance very visible services, infrastructural projects and other essential utilities [15]. Individuals promoting urban revitalization hold that benefits from developments do not accrue solely to developers and landlords; instead they also improve values of surrounding properties and neighborhoods, while also increasing the tax base for municipal governments [16]. Bird argued that property tax is a good tax for local government because it is fair, 
difficult to evade, and promotes local autonomy and accountability [17]. Almost all local governments worldwide rely, to some extent, on property tax to pay for local services [18]. Bird \& Slaik [19] in their study on land and property taxation provided an insight into the importance of generation of property taxes within a locality. It was stressed that property tax is appropriate as a local revenue source because real property is immovable and domiciled within a community, thus it is unable to shift location in response to the tax. The study also revealed that property tax is considered as an appropriate source of revenue for local government as there is the connection between many of the services typically funded at the local level and the benefit to property values. The study concluded that property tax is a benefit tax to the extent that public services and infrastructural development provided to the property owner and the society enhance the value of the property and result in higher property taxes. Similarly, Song and Yuez, [20] in examining how differences in property within cities affect urban sprawl, established through a rigorous mathematical model that there is a relationship between property tax and change in improvement on land via the ability of residents to pay for what they can afford.

\section{Legal Framework of Land and Property Taxation}

The aggressive revenue drive by the government of Lagos state partly dictated its' action to fuse the various forms of multiple taxes, namely, Land Rates Law (Cap. 112), Neighborhood Improvement Charge Law (Cap 136), and Tenement Rate Law (Cap. 186) into the Land Use Charge Law (2001). The law imposes a land based charge which is payable on all real properties in Lagos State [21]. However the law permits any Local Government Council to delegate to the State, by written agreement only, such assessment and collection powers [22]. Section 16 provides for transparent implementation of the consolidation and delegation agreement, also, provides for the establishment and maintenance of a Land Use Charge Collection Fund by the Commissioner for Finance, for the sole aim of determining the amount realized and for sharing and disbursement to the participating Local Government Councils (LGC) within 10 days thereafter. The law further provides in section 22 [23] that the provisions of the Assessment Law, Land Rate Law, Neighborhood Improvement Charge Law and Tenement Rate Law shall cease to apply to property only when that property is assessed to Land Use Charge. It should be noted that aside from this, other taxes on Land and property exist, they include the following: Capital Gain Tax, Stamp Duties, Consent and Registration Fees, Ground Rates that are predominantly the sources of Rivers State internally generated revenue.

\section{Conclusion}

Land and property taxation plays enormous and significant role in the infrastructural development of a State and as such should be taken seriously, as Lagos State has done. Since the relationship between the trio (Land, property taxation and infrastructural development) cannot be divorced in a sane society, it follows that efforts should be made to harness these taxations in Rivers State so as to be at per with Lagos State in terms of development and strides. However, precaution should be the guiding principle so as not drive away developers from the State, as aptly captured by England, Zhao and Huang [24], in their work, which submitted that property taxes have impacted more negatively on lot size than building size. They further stressed that the significant effect of property taxation on the decision of residential property development provide some evidence that the property taxation is not merely a user fee and that it does affect allocation of residential capital across municipalities.

\section{Acknowledgement}

None.

\section{Conflict of Interest}

No conflict of interest.

\section{References}

1. Tunde Otubu (2010) Land Reforms and The Future of Land Use Act in Nigeria.

2. Omotola JA: Law and Land Rights: Whither Nigeria, University of Lagos Akoka Inaugural Lecture Series 1988 page 6; See also Olagbaiye T: Statutory Regulation of the Environment - An appraisal of the Lagos State Environmental.

3. See Declaration of United Nations Conference on human settlements available at www.un.org/conference/habitat visited on 14th August 2015.

4. Banire MA (2006) Land Management in Nigeria: Towards a New Legal Framework Ecowatch Publication Limited: 4.

5. AJAYI Cyril Ayodele, ONI Ayotunde Olawande (2011) Effects of Property Tax on Sustainable Housing Delivery in Lagos 4(1).

6. Collins C (2003) Infrastructure Advanced Learner English Dictionary, 4th ed. London: Harper Collins Publisher.

7. Tesfay A (2008) Infrastructure Development Enhances National Development.

8. Yemi Osibanjo (2001) Former Attorney General, Lagos state, now, Vice president of the federal Republic of Nigeria.

9. Lagos State Official website

10. 2012 report

11. Olusegun K (2003) Fundamentals of Real Estate Taxation. Olusegun Kuye and Associates, Lagos, Nigeria.

12. Tsoodle LJ, Turner, TM (2008) Property Taxes and Residential Rents. Journal of Real Estate Economics 36(1): 63-80.

13. Slack E (2010) The Property Tax in Theory and Practice. The Institute on Municipal Finance and Governance.

14. England RW, Zhao MQ, \& Huang JC (2013) Impacts of Property Taxation on Residential Real Estate Development. Journal of Housing Economics 22(1): 45-53.

15. Ajayi MTA, Ogunbajo A Rukaiyat, Sule I Abass, Abdulkareem Sekinat (2015) The Relationship between Residential Property Development and Property Tax generation in Ibadan North, Oyo State.

16. Newel TA (2001) Development and Neighbourhood Revitalization: The Effects of Residential Investment on Property Values in Durham, NC. The Michigan Journal of Business: 97-120.

17. Bird RM (2001) Subnational Revenues: Realities and Prospects. Washington Dc: World Bank Institute.

18. Slack (n 13)

19. Bird RM, Slaik E (2002) Land and Property Taxation: A Review. A working paper of the Lincoln Institute of Land Policy.

20. Song Y, Yuez Z (2006) Property Tax and Urban Sprawl: Theory and Implications for US cities. A Lincoln Institute of Land Policy Working Paper WP05Y21 60(3): 519-534 
21. Land Use Charge Law 2001 (LUCL 2001) laws of Lagos State, s.1 22. LUCL2001, s1 (3).
23. LUCL 2001 (n 21).

24. England (n 14). 